Research Article

\section{Regulatory requirements and} assessment of scientific research by a psychiatrist when considering the issue of assigning a qualifying doctor's category

\author{
Shapovalova LA ${ }^{1}$, Shapovalov KA ${ }^{2 *}$ and Shapovalova $\mathrm{PK}^{2}$ \\ ${ }^{1}$ State Autonomous Health Agency of the Republic of Komi "Consultative and Diagnostic Center of \\ the Republic of Komi", Syktyvkar, Republic of Komi, Russian Federation \\ ${ }^{2}$ State Education Agency of Additional Professional Education of the Republic of Komi "Komi \\ Republican Institute for Development of Education", Syktyvkar, Republic of Komi, Russian \\ Federation
}

\section{Abstract}

Introduction: In accordance with the requirements for the preparation of a report, a physician must provide information on scientific research in the following sections to obtain a qualification category of a specialist: 6 . Scientific and practical work (participation in scientific and practical conferences, medical scientific societies, presentations, publications); 11.2. List of publications of the attested in scientific journals and collections, abstracts and 11.3. List of speeches at international, all-Russian and republican conferences.

Material and methods: The analysis of 5 qualification works of a psychiatrist (1997, 2002, 2008, 2013 and 2018) for the scientific component as part of the mandatory requirements for the processing of documents when they are submitted to the Attestation Commission on the assignment of a qualifying medical category in psychiatry. The depth of the study was 24 years. When working on the material, the following methodical approaches were used: system, complex, dynamic, normative, quantitative and situational. Methods of analysis included: historical, analytical and comparison. For the analysis, methods were used: groupings, absolute values, continuous and selective observations.

Results: The psychiatrist GAUZ "KDC" independently or in co-authorship published 223 scientific and educational-methodical publications (total volume of 182.65 conventional author's sheets), including 90 scientific (39.81) and 143 educational-methodical (142.84) works, in including one monograph and eight textbooks (two of them with the stamp of the Ministry of Education of the Russian Federation). In the e-library (www.e-library.ru) of the Russian Scientific Citation Index (RINC): publications - 31; citations - 123; Hirsch index - 3, publications in the journals of the VAK - 13. (https://elibrary.ru/author).

Discussion: The scientific work of a practicing outpatient psychiatrist is assessed both quantitatively and qualitatively, the integral indicator of the psychiatrist's own participation in each publication of 0.78 conventional printed sheets can be considered as a serious personal contribution to scientific research.

In the regulatory framework of indicators and requirements for registration of the report there is no synchronization in the daily work of a practical doctor, his job duties with the statements of the report. When concluding an employment contract with the employer, there is no mention in it that the doctor should engage in scientific work, and it is an integral part of his functional duties and qualification requirements. The scientific work does not mention the "Unified qualification directory of positions of managers, specialists and employees, the section "Qualification characteristics of the positions of employees in the field of health care" for a psychiatrist.

Conclusion: The attitude to the Administrative Regulations on the provision of a public service for assigning a qualification category to specialists engaged in medical and pharmaceutical activities should be reviewed in terms of synchronization with the duties of a doctor. The Regulation on the compulsory conduct of scientific research should be introduced, substantiated and provided by the employer or be excluded from the administrative regulations as an independent section and be exclusively recommendatory in nature.

\section{More Information}

*Address for Correspondence:

Shapovalov Konstantin Albertovich, State Education Agency of Additional Professional Ed-ucation of the Republic of Komi "Komi Republican Institute for Development of Education", Syktyvkar, Republic of Komi, Russian Federation, Email: stampdu@rambler.ru

Submitted: April 03, 2021

Approved: April 19, 2021

Published: April 20, 2021

How to cite this article: Shapovalova LA, Shapovalov KA, Shapovalova PK. Regulatory requirements and assessment of scientific research by a psychiatrist when considering the issue of assigning a qualifying doctor's category Arch Psychiatr Ment Health. 2021; 5: 025-032.

DOI: 10.29328/journal.apmh.1001032

ORCiD: orcid.org/0000-0003-4803-0009

Copyright: @ 2021 Shapovalova LA, et al. This is an open access article distributed under the Creative Commons Attribution License, which permits unrestricted use, distribution, and reproduction in any medium, provided the original work is properly cited.

Keywords: Scientific work; Qualification category; Psychiatrist

\section{Check for updates}

OPEN ACCESS 
Publications of physicians in scientific journals and collections, theses of reports should motivate their interest, and within the limits of the possibilities of the medical institution to have reasonable financial support, fixed in the employment contract.

An example of a practical doctor who speaks at international, all-Russian or republican congresses, congresses and conferences is an important indicator of his professional growth, an incentive for the disclosure and development of the potential of the medical institution team and the result of proper administrative and organizational-methodological guidance.

The scientific work and publications of a psychiatrist's practical doctor should be a weighty additional argument in favor of a positive decision on awarding the qualification category he has declared.

\section{Introduction}

The Regulation on the provision of public services for the assignment of a qualification category for the preparation of a report for specialists with higher medical and pharmaceutical education formulates provisions on the scientific research of a doctor in two sections as follows: Section 6. Scientific and practical work (participation in scientific and practical conferences, medical scientific societies, speeches with reports, publications); Section 11. 2. List of publications of the attested in scientific journals and collections, abstracts and 11.3. List of speeches at international, all-Russian and republican conferences [Appendix No. 3 to the Administrative Regulations for the provision of public services for the assignment of a qualification category to specialists carrying out medical and pharmaceutical activities in the Republic of Komi, in the manner prescribed by the authorized federal executive body]. It follows from this that a doctor who draws up documents for a qualification category must be engaged in scientific work, have publications in scientific journals and speak at scientific conferences [1-5].

\section{Material and methods}

The analysis of 5 qualification works of a psychiatrist was carried out in 1997 (for 1994-1996), 2002 (for 1999-2001), 2008 (for 2005-2007), 2013 (for 2010-2012) and 2018 (for 2015-2017) for the scientific component as part of the mandatory requirements for paperwork when submitting them to the Attestation Commission for the assignment of a qualifying medical category in psychiatry. The depth of the study was 24 years [6-10].

On 04.07.1997, the attestation commission under the Ministry of Labor and Social Development of the Russian Federation (Moscow) was awarded the highest qualification category in the specialty "Psychiatry", which was confirmed in December 2002 by the attestation commission of the St. Petersburg Institute of Advanced Medical Expertise, and 18.04.2008, 28.03.2013 and 20.02.2018 - by the Republican Attestation Commission of the Ministry of Health of the Komi Republic.

When working on the material, the following methodological approaches were used: systemic, complex, dynamic, normative, quantitative and situational. Analysis methods included: historical, analytical and comparison. The following techniques were used for the analysis: groupings, absolute values, continuous and selective observations.

\section{Results}

Formation of the scientific interests of the future doctor begins in the classrooms of the medical institute in student scientific circles, and in each case it happens in different ways. As a rule, one of several directions is chosen, which becomes the scientific dominant and determines the face of the researcher. However, depending on situations, other effective parallel studies in various fields of medicine are often possible, if they touch on general medical issues and (or) a doctor's specialization is constantly in demand when he works in a stable scientific group on interdisciplinary problems.

In the analyzed case, the future psychiatrist was engaged in student scientific circles of the departments of topographic anatomy and operative surgery, dermato-venereology and psychiatry of the Arkhangelsk State Medical Institute (ASMI), was involved in scientific research at the department of psychiatry of the ASMI while studying in clinical residency, taught psychiatry and neuroscience medicine college.

Therefore, in the field of scientific interests were: Psychiatry. Mental health and morbidity of the population. Public health and health care of the subarctic region. Social medicine. Implementation of ITU recommendations for the rehabilitation of patients in various professional and age groups. Preventive medicine. Methods of teaching the basics of life safety, emergency medical care in case of injuries and accidents, healthy lifestyle and health-preserving technologies, social and hygienic consequences of HIV infection (AIDS), sexually transmitted diseases and bad habits (tobacco, alcohol, toxic and drug use) substances) in higher and secondary vocational educational institutions. Didactics of subjects "Safety of life" and "Fundamentals of a healthy lifestyle" for non-medical faculties of humanitarian and technical universities. Distance and additional education, active forms of education [11-15].

The psychiatrist, independently or in co-authorship, published 284 scientific and educational-methodical publications with a personal total volume of 197.85 conventional author's sheets (40,000 printed characters), of which scientific - 141 (55.01) and educational-methodical 143 (142.84) works, including 1 monograph and 8 textbooks (two of them Recommended by the Presidium of the Council of Educational Methodological Association of Russian universities in the field of teacher education as a textbook for students of higher educational institutions, students majoring 
on discipline 033300 "Safety"). In the e-library (www.elibrary.ru) of the Russian Science Citation Index (RSCI): publications - 47; citations - 273; Hirsch index - 4, publications in VAK list journals - 16, weighted average impact factor of journals in which articles were published - 0.902, weighted average impact factor of journals in which articles were cited - 0.231. Elsevier Mendeley scientific metric system has 284 publications [16-18].

In the Russian State Library (Moscow) in the Unified Electronic Catalog 4 textbooks are presented (www.rsl.ru).

In the Russian National Library (St. Petersburg) in the electronic catalog there are 4 textbooks (www.nlr.ru).

Two textbooks were presented at the collective stand of the "Universities of Russia" exposition at the $55^{\text {th }}$ International Book Fair in Frankfurt am Main (Germany), which after graduation entered the library of the University of Frankfurt (2003). The Presidium of the Council of the Educational and Methodological Association for the specialties of pedagogical education awarded both books the "Label of textbooks for students of higher educational institutions" (2004).

The National Library of the Komi Republic contains 3 textbooks [19-22].

Psychiatrist abroad: "European Psychiatry", "Archives of Psychiatry and Mental Health", "Annals of Psychiatry and Treatment", "Advances in Psychology Research", "Psychiatry, psychotherapy and clinical psychology", "OA Alcohol”, “ Prehospital and Disaster Medicine, Trauma and Emergency Care, Archives of Surgery and Clinical Research; domestic: "Psychiatry", "Mental Health", "Independent Psychiatric Journal", "Alma mater (Bulletin of the Higher School)", "Teacher XXI century", "Life Safety", "Life and Safety", "OBZH. Fundamentals of Life Safety "and other Russian scientific and practical journals published (co-authored) 74 articles [23-36].

In the scientific library of dissertations and abstracts disserCat http://www.dissercat.com, the works of a practical doctor are cited in 6 dissertations in 5 scientific specialties (03.00.13 Physiology (2); 03.02.08 Ecology (1); 05.18 .15 Commodity science of food products and technology of public catering products (1); 12.00.08 Criminal law and criminology; penal law (1) and 13.00.08 Theory and methodology of vocational education (1), which indicates a broad scientific outlook of the researcher.

Research by a practical psychiatrist is published in the proceedings of the World and 3 European Congresses of Psychiatrists.

$\checkmark$ EPA 2017 25th European Congress of Psychiatry. 1-4 April, 2017. Florence, Italy;

$\checkmark$ EPA 2018 26th European Congress of Psychiatry. 3-6 March, 2018. Nice, France; $\checkmark$ WPA 2018 World Psychiatric Assosiations Tematic Congres "Innovation in Psychiatry: Effective Interventions for Health \& Society". 25-28 February 2018 Melburne, Australia;

$\checkmark$ EPA 2019 27th European Congress of Psychiatry. 6-9 April, 2019. Warzawa, Poland.

11 reports were presented at regional, zonal, all-Russian, international scientific and practical seminars, conferences, symposia and congresses (in co-authorship) [37-51].

\section{Discussion}

The scientific work of an outpatient psychiatrist practitioner is difficult to assess, since, on the one hand, its implementation is of a recommendatory and not mandatory nature, on the other hand, it is very clearly characterized by an interest in analyzing the results of one's own work, creativity and scientific activity $[52,53]$.

The first indicator of any analysis is, of course, quantitative results. And in this case, they are convincing enough for a scientist of any qualification, especially a practical doctor. The total personal volume of works amounted to 197.85 conventional author's pages (each 40,000 characters). A qualitative analysis of works, first of all, determines the ratio of works published in scientific publications (141): monographs, scientific and practical and scientific methodological journals, collections of works of scientific and practical congresses, congresses, conferences, including international ones, and educational and methodological publications (143). The next question to be answered is what the author writes: numerous abstracts of 3 paragraphs for 12-18, or even 25 authors (the so-called "mass graves") or scientific monographs and journal articles. The integral indicator of the psychiatrist's personal participation in each publication of 0.70 conditional printed sheet characterizes a solid volume of personal contribution to scientific research.

Serious work on two textbooks over 10 years, their relevance, expressed in a 4-fold reprint, was appreciated not only by users (students, cadets), but also by the scientific community: in 2004, both publications were awarded the stamp of the Ministry of Education of the Russian Federation. Publications of the practitioner are presented in national libraries. They can be found on the pages of 13 different domestic and foreign scientific and practical journals.

How to evaluate these results? Based on e-library materials, three leading scientists of the Russian Federation (RF) published an average of (No. $1=24215+$ No. $2=5575+$ No. 3 = 5438): 3 = 11742.7 scientific papers each. If we assume that the average duration of the scientific activity of a modern scientist is 50 calendar years (from 22-25 to 72-75 years), then the leaders of scientific research publish annually 234.9 works (not only articles, but also monographs and textbooks) during 290-300 working days (two jobs in 3 days). If we take 
the results of three leading scientists in medical specialties, the results will be more modest (No $2=5575+$ No $28=1484+$ No 43 = 1313): 3 = 2790.6 - 55.8 jobs per year, 4.7 jobs per month, 1 job per week, but still beyond the reach of a practitioner.

Modern science began to measure the value of publications by scientific metric indicators, including the number of citations. The indicator is important, but not very objective and, to some extent, quite "crafty". In the modern world of scientific journals, a huge number of scientific journals are published (including in electronic form), but their availability is sharply limited due to very small circulations, as well as payment for electronic copies, if they are provided by editors, publishers or Internet libraries. At present, it is difficult to imagine yourself a provincial doctor who independently subscribes two or three professional journals at the same time (as a rule, published by leading scientific research centers or institutes of psychiatry in Moscow and St. Petersburg, plus something else from Europe or the USA on the generally accepted English language). But such a situation was quite common in every department of any Soviet hospital 25-30 years ago (there were international magazines from friendly countries of Eastern Europe in Russian). Since then, writing and publishing have become many times more, and the results of research have become much less read and applied in practice, mainly due to the financial inaccessibility of scientific periodicals and the lack of awareness of their results. And, nevertheless, there is an e-library (www.e-library.ru) and the Russian Science Citation Index (RSCI), which conduct a comprehensive analysis of the author's publications online, calculate all kinds of indices and indicators. It turned out that the RSCI represented only $13.90 \%$ of the discussed scientific and educational-methodical publications of a practical doctor. This significantly reduces the scientific rating, which is not always justified by most modern scientists. The reason lies in the limited availability of the RSCI for practical independent users, since this is an ordinary commercial project. For the placement of publications of scientists published in journals, the Internet portal bears the costs, and for the introduction and correction of personal printed works outside of periodicals a scientific institution. There is no reason to hope for some kind of payment from practical doctors of non-scientific and non-educational state medical institutions of the RSCI. Thus, scientific citation is carried out objectively only for registered scientists, scientific and educational institutions that pay for these services.

For the objectivity of the assessment of scientific work, it is important to understand how the researcher works: on a continuous basis or from time to time. To this end, it is important to know the scientific metric indicators of the researcher's scientific publications over the past 3-5 years. They can be low, including among professional scientific workers, or, conversely, command respect, as in this particular case.
At the head of the practical significance of any scientific publication at the present time, from the stand point of curators of scientific metric projects and portals, the absolute number of its citations by other authors is put. And this important indicator may contain a certain amount of guile. How often do readers of scientific publications and publications that are freely available in libraries or the Internet cite the text they have read? Judge for yourself: three articles by authors published in 2013 in one of the international electronic journals OA Publishing London, at the time of this writing (after 6 years), according to the automated portal program, respectively, have 14303, 14146 and 11676 views and - not a single citation, for example, in the Web of Science. Researchers and users watch, perhaps read and even copy freely available pdf files, but do not feel it necessary to cite literary sources (the unpredictable Internet!). On the other hand, 40,125 readers showed interest in works from Russia. This is also a very significant result. However, views are not citations, and the scientific community treats them as "emoticons" interested smiles from the Internet and nothing more.

It should be noted that only authors of dissertations for the degree of candidates and doctors of sciences are extremely careful (scrupulous) and conscientiously citing, since they need to recruit 150-200-300 authors-predecessors for the solidity of the study. And in such works, they try to cite all the authors who published works on this topic. In Russia, there is a special site for the Scientific Electronic Library of Dissertations and Abstracts (Pubmed: https:// www.dissercat.com/), the fund of which is more than 740 thousand research papers - over 440 thousand theses (386 thousand candidate and 54 thousand doctoral works) and 300 thousand abstracts and reflects the entire modern science of the country and its development. A list of citations of each dissertation is freely available, that is, the scientific works of the author's predecessors and contemporaries in demand. It is reasonable to place these citation results in the RSCI, but the copyright holder of Dissercat.com and the possible assignee for some reason still do not do this. And only if the dissertation candidates independently post their work in the RSCI, it is possible to find out the authors of the cited scientific works and objectively evaluate their Hirsch index.

In an ordinary journal (non-dissertation) article, the task of comprehensive citation is not worth it. The editors strongly limit the number of citations for articles to 10-15 sources, literary reviews - 30-45 in the conditions for authors. And thus, many studies are not mentioned and remain outside the main scientific indicator. Sometimes the authors are not mentioned intentionally, since they work in the same scientific direction or they are mentioned necessarily and repeatedly, since they can be (or become) the most likely reviewers of the article, employers, scientific advisors of the author, reviewers of the dissertation work or its opponents.

In order for an article to start "living" in modern scientific 
life, it must not only be written and published, but also entered into the electronic databases of libraries and the world's authoritative search platforms Scopus, Web of Science and others. How to do this if your organization is not a subscriber of the RSCI, and it does not have an authorized person to do this. There is only one way - the citation itself in the next article, if it gets into the scientific system automatically. But this citation will not be taken into account as an equal citation in the scientific profile for calculating the Hirsch index and will be attributed to a rather humiliating and not respected category - "citation itself".

Authors often independently find in Internet publications citing their works by colleagues working in parallel scientific areas, but if these publications have not concluded an agreement, do not pay for services, then there is no citation. Copyright holders must enter all information about the publication and citation themselves, including in the RSCI. No payment - no citation.

Often, researchers make mistakes not only in the names of the authors, but even in the titles of the journals, so the mentioned scientific work will never be included in the list of their citations. For example, in one Russian scientific publication, when citing the Far Eastern Medical Journal, it is named as the Marine Medical Journal. The citation itself is not in the RSCI, but the work is hosted by Mendeley.com, a Scopus subsidiary platform. To correct inaccuracies, it is necessary to enter into a legal relationship with the citing platform, which for the practitioner presents long-term unpredictable difficulties, which are usually ruled out as unnecessary.

Thus, over the past 20 years, systems of domestic and international citation of scientific publications have been created with good intentions, which requires complex legal and financial regulation of relations between scientists, research centers and the citing organization.

Understanding even a small part of the above arguments, people who are able to effectively engage in scientific research do not embark on this thorny path or curtail their already begun activities. Motivation, as a rule, comes down to the wording: "The time and money are huge - the practical results are questionable." Why go on with this?

Therefore, at present, practice shows that in most cases, practitioners are increasingly refraining from discussing the results of their work and publishing them not only in the scientific press, but also presenting them to the Attestation Commissions due to the large expenditure of personal time for registration of work and low financial motivation. in case of successful completion of certification and assignment of a medical qualification category. Having accepted by appointment after the main working appointment, two or three patients per month on a paid basis, they easily compensate for wages in the absence of a qualification category.
The regulatory framework of indicators and requirements for the presentation of the report is also far from perfect. Legal expertise (lawyer, actual state adviser of the 3rd class of the Komi Republic Shapovalova P.K.) notes that there is no synchronization in the daily work of a practical doctor, his job duties with the wording of the Regulations. When concluding an employment contract with an employer, it does not mention that a doctor must be engaged in scientific work, and it is an integral part of his functional duties and qualification requirements. Scientific work is not mentioned in the current Order of the Ministry of Health and Social Development of the Russian Federation of July 23, $2010 \mathrm{~N}$ 541n "On Approval of the Unified Qualification Handbook of the Positions of Managers, Specialists and Employees, the section" Qualification characteristics of positions of workers in the healthcare sector "(Registered in the Ministry of Justice of the Russian Federation on August 25, $2010 \mathrm{~N}$ 18247). But the Order of the Ministry of Health No. 240n of 04/23/2013 "On the Procedure and Terms of Certification for Medical Workers and Pharmaceutical Workers to Obtain a Qualification Category" equally interprets the qualification requirements for the second, first and highest category of a doctor in the context of scientific work (Registered with the Ministry of Justice of the Russian Federation on July 5 2013): a specialist should orient himself in modern scientific and technical information and use it in his professional activities, but to orientate does not mean to engage in research work and publish its results.

In most medical institutions at the level of rural, district, and individual city hospitals, scientific work is not carried out at all, since there is no material base for this, no administrative, methodological and scientific leadership. And only during the departure for advanced training to central universities, interested doctors can join scientific research, and some of them find a scientific advisor, determine the topic, carry out and successfully defend dissertations. If there are no requirements to engage in scientific work in the doctor's job description, and they are not included in his functional duties, then in most cases there can be no scientific results and their publications. Therefore, there is no reason to require a mandatory report on scientific research from a doctor, all the more to introduce an independent section in the Regulations for qualifying work. Doctors find a way out of the situation in different ways. Most often, in most qualifying works, they avoid numbering sections in accordance with the requirements, and section 6 automatically disappears. Scientific work. But if from the first day of work of a doctor, official duties obliged him to engage in scientific work, then after 3, 5, 7 years (minimum work experience in the specialty for the award of the second, first and highest qualification categories, respectively) she would no doubt have been presented.

The regulatory framework of indicators and requirements for the presentation of the report is also far from perfect. 
Legal expertise (lawyer, actual state adviser of the 3rd class of the Komi Republic Shapovalova P.K.) notes that there is no synchronization in the daily work of a practical doctor, his job duties with the wording of the Regulations. When concluding an employment contract with an employer, it does not mention that a doctor must be engaged in scientific work, and it is an integral part of his functional duties and qualification requirements. Scientific work is not mentioned in the current Order of the Ministry of Health and Social Development of the Russian Federation of July 23, $2010 \mathrm{~N}$ 541n "On Approval of the Unified Qualification Handbook of the Positions of Managers, Specialists and Employees, the section" Qualification characteristics of positions of workers in the healthcare sector "(Registered in the Ministry of Justice of the Russian Federation on August 25, 2010 N 18247). But the Order of the Ministry of Health No. 240n of 04/23/2013 "On the Procedure and Terms of Certification for Medical Workers and Pharmaceutical Workers to Obtain a Qualification Category" equally interprets the qualification requirements for the second, first and highest category of a doctor in the context of scientific work (Registered with the Ministry of Justice of the Russian Federation on July 5 2013): a specialist should orient himself in modern scientific and technical information and use it in his professional activities, but to orientate does not mean to engage in research work and publish its results. The second important aspect of this problem is that the employer, represented by the chief physician, does not motivate employees to engage in scientific research. What follows the performance of the work - its report at a scientific conference, as a rule, on the road to a regional, and more often a central city. The path from Petropavlovsk-Kamchatsky to St. Petersburg is not close and very expensive. It is necessary to pay for organizational costs and travel, which in the conditions of self-financing of medical institutions is not always possible, especially in large quantities. Publishing in a scientific journal becomes an exorbitant burden on physicians and researchers. Editors set a variety of tariffs from a sparing 8 thousand rubles per article to 5 thousand rubles per page. Electronic mailboxes are overflowing with offers of publications in foreign journals, but the cost in some of them exceeds 20002500 conventional units, and even the promise of subsequent citation in the Scopus system does not arouse the desire for such "expensive" scientific cooperation. Therefore Section 11.2. The list of publications certified in scientific journals and collections, abstracts of reports is a serious test for a practical doctor and requires guarantees of financial support from the employer, which makes such serious demands on him. Although it is difficult to imagine that a public health institution would pay significant sums for the publications of doctors, especially in mass numbers. Currently, a relatively good indicator is considered if more than half of the doctors of a medical institution have qualification categories. That is, every second specialist of a medical institution potentially not only can, but should also be the author of a scientific research.
The third problem is formulated in clause 11.3. List of speeches at international, all-Russian and republican conferences. For a modern practitioner to prepare and present his report on the materials of the section of his own results of certification work does not seem to be a timeconsuming process. Submitting an application and receiving positive feedback from an anonymous reviewer is already a great success for the practitioner. What's next? What decision will the employer make? Will he send the employee on a paid business trip, which will become an example and incentive for the rest of the medical team. The question is the price. The All-Russian conference, the congress will cost 25-30,000 rubles, and the international one, where only the registration fee is 500-600 conventional units, is not less than 1800-2000 USD. And here the administration, perhaps, will only smile in response and offer to look for other payment options, including scientific grants, which can be extremely difficult to obtain (and for a practitioner from the provinces, it is simply impossible) or to use personal funds (with the wording "at the expense next labor leave "). But, please note that the doctor's qualification report will not be complete if the above item is not filled out.

It is extremely rare, but it is also possible to manipulate the scientific section by the administration and (or) the qualification commission, when the doctor is detained, postponed or downgraded due to the absence, "insufficient" or "poor quality" of scientific publications in the qualification 3-year period under consideration.

With the growth of qualification requirements, the volume of work, as well as the financial costs of its registration and technical support, grows significantly. If the first qualifying papers were allowed to be submitted with a font of size 12 with 1 line spacing, nowadays - font 14 with 1.5 spacing, which significantly increases the volume of attestation work in pages. And this entails an increase in the cost of technical support for the qualifying work of a doctor: paper, printer, etc.

\section{Conclusion}

The attitude to the Administrative Regulations for the provision of public services for the assignment of a qualification category to specialists engaged in medical and pharmaceutical activities should be revised in terms of its synchronization with the official duties of a doctor. The provision on the compulsory conduct of scientific research should be introduced, substantiated and provided by the employer, or be excluded from the administrative regulations as an independent section and be exclusively advisory in nature.

Publications of doctors in scientific journals and collections, abstracts of reports should motivate their interest and, within the capabilities of a medical institution, have reasonable financial support, enshrined in an employment contract. 
An example of a practitioner who makes a report at international, all-Russian or republican congresses, congresses and conferences is an important indicator of his professional growth, an incentive for the disclosure and development of the creative potential of the team of a medical institution and the result of his correct administrative, organizational and methodological leadership.

Scientific work and publications of a practicing psychiatrist should become a weighty additional argument in favor of a positive decision on awarding the qualification category declared by him.

\section{Acknowledgment}

The authors express their sincere love to their parents. The authors are grateful to Muratova I.D., Stepanov A.F., Ipatko I.A., Nosov O.P., Repina G.V., Mordvinkova L.V., Krasteva-Gavrilova A.G., as well as all anonymous reviewers for support, valuable advice and helpful comments.

\section{References}

1. Order of the Ministry of Health No. 240n dated 04/23/2013 "On the Procedure and Dates of Passing Certification by Medical and Pharmaceutical Workers to Receive a Qualification Category". (Registered in the Ministry of Justice of the Russian Federation on July 5, 2013).

2. Order of the Ministry of Health and Social Development of the Russian

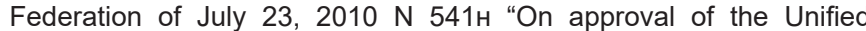
Qualification Guide for the positions of managers, specialists and employees, section" Qualification Characteristics of the Positions of Workers in the Field of Health Care "(Registered in the Ministry of Justice of the Russian Federation on August 25, 2010 N 18247).

3. Appendix No. 3 to the Administrative Regulation for the provision of public services for the assignment of a qualification category to specialists engaged in medical and pharmaceutical activities in the territory of the Komi Republic, in the manner established by the authorized federal executive body.

4. Professor SN. Mosolov: Naukometricheskie pokazateli - vazhnye kriterii ocenki rezul'tatov nauchnoj deyatel'nosti. Interv'yu. Rossijskij psihiatricheskij zhurnal. 2018; 2: 88-91.

5. Kazakov RA. Optimizaciya nauchnoj deyatel'nosti medicinskoj organizacii na osnove principov menedzhmenta kachestva. Avtoreferat na soiskanie uchyonoj stepeni kandidata medicinskih nauk. Novosibirsk. 2014. https://www.dissercat.com/content/optimizatsiyanauchnoi-deyatelnosti-meditsinskoi-organizatsii-na-osnove-printsipovmenedzhme

6. Shapovalova LA. Organization of work of the specialized psychiatric bureau of medical and social expertise in 1994-1996 Syktyvkar, 1997.

7. Shapovalova LA. Certification materials of a psychotherapist of the Republican Center for Socio-psychological, medical rehabilitation of former military personnel and persons with disabilities. Syktyvkar, 2002.

8. Shapovalova LA. On the Work of the Psychiatrist of Advisory Department of State Agency of Health "Advisory and Diagnostic Centre of the Republic of Komi” in 2005-2007. Syktyvkar, 2007.

9. Shapovalova LA. Analysis of the Work of the Psychiatrist of Avisory Departmet of the State Autonomous Health Agency of the Republic of Komi "Consultive and Diagnostic Centre of the Republic of Komi" in 2010-2012. Syktyvkar, 2012.

10. Shapovalova LA. Analysis of the Work of the Psychiatrist of Avisory Departmet of the State Autonomous Health Agency of the Republic of Komi "Consultive and Diagnostic Centre of the Republic of Komi" in 2015-2017. Syktyvkar, 2018.

11. Shapovalov KA, Shapovalova LA. Bases of didactics of an educational theme "Training of the population to first-aid treatment at thermal defeats, electric, thermal and beam burns, freezing injuries in the conditions of emergency situations». Bezopasnost Zhiznedejatelnosti 2015; 4: 67-72.

12. Niculina TI, Shapovalov KA, Shapovalova LA. Additional professional training program of teachers of educational institutions "Providing first emergency aid to victims". Syktyvkar, Komi Republican Institute for Educational Development. 2016.

13. Shapovalov KA, Shapovalova LA. Basics of Didactics of Theme "Closed Damages" of Training Module "The First (Pre-Medical Emergency) Assistance for Traumas Suffered During Accidents, Catastrophes and Natural Disasters" of Subject "Life Safety" for Humanitarian and Technical Universities. Bezopasnost Zhiznedejatelnosti. 2016; 2: 56-64.

14. Shapovalov KA, Shapovalova LA. Basics of Didactics of Theme "Bleeding" of Training Module "The First (Pre-Medical Emergency) Assistance for Traumas Suffered During Accidents, Catastrophes and Natural Disasters" of Subject "Life Safety" for Humanitarian and Technical Universities. Bezopasnost Zhiznedejatelnosti. 2016; 4: 51-61.

15. Shapovalov KA, Shapovalova LA. Bases of Didactics of Theme "Fractures" of Educational Module "The First (Pre-Medical Emergency) Assistance for Injuries Suffered During Accidents, Catastrophes and Natural Disasters" of Subject "Safety" for Humanitarian and Technical Universities. Bezopasnost Zhiznedejatelnosti. 2016; 7: 54-61.

16. Shapovalov KA, Shapovalova LA. Additional Professonal Training Program of Distance Learning Course "First Aid for Injuries and Accidents". Syktyvkar, Komi Republican Institute for Educational Development, 2017

17. Shapovalov KA, Shapovalova LA. Bases of Didactics of Theme "Damage to the Head, Neck and Spinal Column" of Educational Module "The First (Pre-Medical Emergency) Assistance for Traumas Suffered During Accidents, Catastrophes and Natural Disasters" of Subject "Life Safety" for Humanitarian and Technical Universities. Bezopasnost Zhiznedejatelnosti. 2017; 4: 54-64.

18. Shapovalov KA, Shapovalova LA, Yastrebtseva T, Gusarova S, Bairova E. Disabled children. Standards of primary, general disability, major violations in health status and leading disability of disabled children in city children's polyclinic of regional center of subarctic territory. Pediatrics. Eastern Europe. 2017; 5: 254-269.

19. Shapovalova LA, Shapovalov KA. Features of work of psychiatrist of Regional consultative diagnostic center of Subarctic Territory. Independent Psychiatric J. 2016; 3: 68-74.

20. Shapovalov KA, Shapovalova LA. Methodological approaches to teaching academic theme "Wounds" of subject "First aid for injuries suffered during accidents, catasthrophes and natural disasters" for humanitarian and technical universities. 19th World Congress for Disaster and Emergency Medicine. 2015; 380.

21. Shapovalov KA, Shapovalova LA. The Author's Program of Subject "First Aid for Traumas in Accidents and Natural Disasters" for Nonmedical Faculties of Humanities and Technical Universities. 19th World Congress for Disaster and Emergency Medicine, 21-24 April 2015, Cape Town, South Africa. Abstracts 634.

22. Shapovalov KA, Shapovalova LA. Didactic of Training Topic "Fetal Alcohol Syndrome". 3d ASIAN CLINICAL CONGRESS (ACC3). Tokio, Japan. 2015.

23. Shapovalov KA, Shapovalova LA. Demographic Characteristics of the Cohort of Patients, Receiving Outpatient Psychiatric Help in Regional Medical Consultative and Diagnostic Center of Sub-Arctic Territory. European Psychiatry. 2017; 41: 578.

24. Shapovalov K, Shapovalova L. Structure of Psychic Sphere Pathology of Patients of the Regional Medical Consultative and Diagnostic Center of Sub-Arctic Territory. European Psychiatry. 2017; 41: 578-579. 
25. Shapovalov KA, Shapovalova LA. First Aid for Wounds to Victims of Accidents, Catastrophes and Natural Disasters. Geneva: World Health Organization. 2017; 1-20.

26. Shapovalov KA, Shapovalova LA. First Aid for Head, Neck and Spine Injuries to Victims of Accidents, Catastrophes and Natural Disasters. Geneva: World Health Organization. 2017; 1-47.

27. Shapovalov KA, Shapovalova LA. Standard of primary disability for city children's clinic of regional centre of subarctic territory. Arch Dis Child. 2017; 102: A114.

28. Shapovalov KA, Shapovalova LA. Control over execution of individua program of rehabilitation and (or) habilitation of children with disabilities. experience of city children's clinic of regional centre of subarctic territory. Arch Dis Child. 2017; 102: A114-A115.

29. Shapovalov KA, Shapovalova LA. Methodological approaches to teaching academic theme "Burns" subject "First aid for injuries suffered during accidents" for humanitarian and technical universities. WCICT 2017 WOUND CARE From Innovations to Clinical Trials. Abstracts No. 1012. 2017.

30. Shapovalov KA, Shapovalova LA. Organization of emergency care at occupational wounds to members of vessel's crews on ships of the Northern water's basin. WCICT 2017 WOUND CARE From Innovations to Clinical Trials. Abstracts No. 1014. 20-21. 2017.

31. Shapovalov KA, Shapovalova LA. Author's Program of Subject «Fundamentals of a Healthy Lifestyle» for Non-Medical Faculties of Humanitarian and Technical Universities. ICSS 2017 International Conference on Social Sciences \& Interdisciplinary Studies. Abstracts Ref. No: ICSS-ABS-APR-241. 2017.

32. Shapovalov KA, Shapovalova LA. The Author's Training Program and Methodical Complex "Basics of a Healthy LifeStyle» for the Prevention of Traumatism of Members of Vessel's Crew. GPC 2017 2nd International Conference on General Practice \& Primary Care. Abstracts Ref. No: GPC-ABS-APR-82. 2017.

33. Shapovalov KA, Shapovalova LA. Traumatism in alcoholic intoxication as marker of dependence or progressive disease on example of fishermen of the Northern water's basin. WPA 2018 World Psychiatric Associations Thematic Congress "INNOVATION IN PSYCHIATRY: EFFECTIVE INTERVENTIONS FOR HEALTH \& SOCIETY”. 25-28. 2018.

34. Shapovalov KA, Shapovalova LA. Scientific research as an integral part of the work of a psychiatrist leading an outpatient consultation in the regional diagnostic center of the Subarctic territory. European Psychiatry. 2018; 48: 755-756.

35. Shapovalova LA, Shapovalov KA. Outpatient Consulting Care of Psychiatrist on Population of SubArctic territory. RC Psych International Congress. 2016.

36. Shapovalova LA, Shapovalov KA. Questions of the Organization and Results of the Work of Psychiatrist of Advisory Department of the Regional Diagnostic Center of Sub-Arctic Territory with Low Population Density. Geneva: World Health Organization. 2016; 1-25.

37. Shapovalova LA, Shapovalov KA. Approbation of new drugs and treatment methods into practice of outpatient psychiatrist at regional diagnostic center of subarctic territory. WPA 2018 World Psychiatric Associations Thematic Congress "INNOVATION IN PSYCHIATRY: EFFECTIVE INTERVENTIONS FOR HEALTH \& SOCIETY". Melbourne, Australia. 2018.

38. Shapovalova LA, Shapovalov KA. Training of psychiatrist of regional diagnostic center of subarctic territory for work in emergency situations of catastrophes and natural disasters. WPA 2018 World Psychiatric Associations Thematic Congress "INNOVATION IN PSYCHIATRY:
EFFECTIVE INTERVENTIONS FOR HEALTH \& SOCIETY". Melbourne, Australia. 2018.

39. Shapovalova LA, Shapovalov KA. Features pathology newly diagnosed by a psychiatrist at the reception of the regional advisory diagnostic center of subarctic territory. European Psychiatry. 2018; 48: 569.

40. Shapovalova LA, Shapovalov KA. Organizational and methodical work as an integral part of the qualification category of a psychiatrist of the consultative department of the regional diagnostic center of the subarctic territory. Mental Health. 2018; 7: 3-11.

41. Shapovalova LA., Shapovalov KA. Characteristics of the pathology of the mental sphere of a contingent of patients on an outpatient visit to a psychiatrist of the consultative and diagnostic center of the subarctic territory. Psychiatry, Psychotherapy and Clinical Psychology. 2018; 9: 515-533.

42. Shapovalova LA, Shapovalov KA. The work of the medical service of civil defense and emergency situations as an integral part of the qualification category of a psychiatrist. Psychiatry (Moscow) (Psihiatriya). 2018; 16: 40-52.

43. Shapovalova LA, Shapovalov KA. Pathology of the psychic sphere in patients with epilepsy, revealed by psychiatrist of the regional consultative center of the Subarctic territory. European Psychiatry. 2018; 48: 718-719.

44. Shapovalova LA, Shapovalov KA. Alcoholic fetal syndrome as obligatory part of lecture on prevention of alcohol use of module "Fundamentals healthy lifestyle" for students of humanitarian and technical universities. European Psychiatry. 2019; 56: 482-483.

45. Shapovalova LA, Shapovalov KA. "Psychiatry of catastrophes" in the daily work of an outpatient psychiatrist. European Psychiatry. 2019; 56: 546.

46. Shapovalova LA, Shapovalov KA. Organizational and methodological work in the practice of psychiatric outpatient consultative reception. European Psychiatry. 2019; 56: 552.

47. Shapovalova LA, Shapovalov KA. Characteristics of mental health of patients of outpatient reception of psychiatrist. European Psychiatry. 2019; 56: 582-583.

48. Shapovalova LA, Shapovalov KA. Diseases of the mental sphere revealed by the psychiatrist at contingent of patients of the consultative outpatient admission. Arch Psychiatry Mental Health 2019; 3: 012-019.

49. Shapovalova LA, Shapovalov KA. Psychiatry of disasters. Organization of the work of a psychiatrist outpatient consultative reception. Ann Psychiatry Treatment. 2019; 3: 012-022.

50. Shapovalov KA, Shapovalova LA, Shapovalova PK. On the issue of registration of the section "Scientific and practical work" of the qualification category of a doctor. IX International congress "Orgzdrav-2021. Good governance in healthcare", Moscow, May 25-27 2021: abstracts. 2021. https://www.vshouz.ru/orgzdrav2021/thesis/27197/

51. Shapovalova LA, Shapovalov KA, Shapovalova PK. The role and place of scientific research in the work of a psychiatrist. Geneva: World Health Organization. 2021; 1-30.

52. Shmukler AB. Dokazatel'nye issledovaniya $v$ psihiatrii: analiz prakticheskoj znachimosti. Psihiatriya i psihofarmakoterapiya. 2012; 14: 4-13. https://www.elibrary.ru/item.asp?id=18903518

53. Ivushkin AA. Sostoyanie nauchnyh issledovanij v psihiatrii na osnovanii naukometricheskogo analiza publikacij otechestvennyh i evropejskogo s"ezdov psihiatrov (2000-2007 gg.). Avtoreferat na soiskanie uchyonoj stepeni kandidata medicinskih nauk. Moskva, 2012. http://mniip-repo. ru/uploads/1341656152.pdf 